\title{
Individuality, Hierarchy, and Dilemma: the Making of Confucian Cultural Citizenship in a Contemporary Chinese Classical School
}

\author{
Canglong Wang ${ }^{1}$
}

Published online: 17 October 2016

(C) The Author(s) 2016. This article is published with open access at Springerlink.com

\begin{abstract}
Is Confucianism compatible with citizenship? If yes, how? Cultural transformation in recent citizenship studies provides a theoretical junction to bring the two concepts together. In terms of cultural citizenship, this paper explores the making of Confucian cultural citizens by analyzing students' discourses in a Chinese Confucian classical school. It reveals (1) the process of moral self-transformation, whereby the individualities are embedded into ethical relations by the extensive readings of classical literature; (2) practically discursive contradictions between individualism and authoritarianism that is based on the notion of a cultural hierarchy; and (3) the institutional predicament in striving for the recognition of cultural citizenship by the state and society. Finally, it concludes that the dilemmas in discourses and status are part of the contradictions in the overall Chinese party-state's management of individualization.
\end{abstract}

Keywords Citizenship · Confucianism · Individualism · Hierarchy · Morality · Ethical · Individualization

\section{Introduction}

Since Engin Isin [7, 13] raised the issue of 'citizenship after orientalism', the study of citizenship in the cosmopolitan academic community has made conscious efforts to cast off the tendencies of essentializing citizenship as an Euro-American framework that generalizes the experiences of other non-Western states or societies, and has reflexively turned to a local perspective in order to investigate the 'roots' of specific citizenship regimes in light of the local conditions of political systems, social structures and cultural recourses. Although citizenship is often seen as a Western conception (see

Canglong Wang

s1460757@sms.ed.ac.uk

1 15a George Square, Edinburgh, UK EH8 9LD 
for example [32], p.vii; [38], p.313), this does not mean there are no acts of citizenship in non-Western societies [11]. As Isin ([11], p.1) convincingly argues, there are increasingly new ways for acts of citizenship to advance the claim for citizenship rights in societies that lack legal or political recognition of the citizenship status.

In critically thinking about Chinese citizenship, we need to consider indigenous resources, for example, Confucianism and the communist party-state system ([14], p.28), together with the Western ideas of citizenship, so as to achieve a better understanding of the Chinese context. In this paper I pay attention to the relationship between Confucianism (Confucian education) and the making of cultural citizenship. At first glance it perhaps seems absurd to mention the two concepts together. This response may arise from a presupposed bias towards both Confucianism and citizenship. As I clarified elsewhere [37], on the one hand, Confucianism has long been considered as a form of authoritarianism rather than liberalism [24], collectivism rather than individualism [8], obligations-orientated rather than rights-orientated [10], and advancing particularism rather than universalism $[4,19,20]$. On the other hand, liberal citizenship has been the mainstream paradigm since T. H. Marshall's classical citizenship framework that equates citizenship with the evolutionary achievements of civil, political and social rights [21]. However, all of these understandings and interpretations are one-sided. By conceptualizing citizenship as either thin or thick and Confucianism as either liberal or illiberal, I theoretically expounded three interpretations: incompatibility (thin citizenship \& illiberal Confucianism), compatibility (thin citizenship \& liberal Confucianism), and reconstruction (thick citizenship \& liberal and illiberal Confucianism) [37].

Nevertheless, the above normative argument neglects a pivotal cultural transformation in recent citizenship studies that unpacks the legal and political aspects of citizenship and turns to the cultural dimension, which, as I will argue in the following, potentially offers a point of contact to connect Confucianism and cultural citizenship as well as to deepen our understanding of 'Confucian (cultural) citizenship'. Traditional citizenship studies did not pay much attention to the cultural dimension of citizenship ([29], pp.1-2), but one's formal legal status, as Turner ([34], pp.11-12) argues, 'is closely associated with the particular cultural forms of law in a given society.' Influenced by globalization, post-modernization and decolonization, the presupposed binding of citizenship and nation-state has begun to unravel, and the fragmentation of public tastes and diversification of lifestyles have impaired the assumed homogeneity of culture [29, 33, 34]. As a result, the claims for cultural citizenship increasingly appear in such areas as new media, education, consumption, and lifestyles, among others, where different cultural groups are able to discursively defend the right or legitimacy of their own cultures and constructively participate in a more inclusive cultural public domain [25-27, 29, 30, 41].

There are two major approaches of cultural citizenship outlined by Delanty [6]: the first approach, represented by Will Kymlicka, is of the view of liberal communitarianism, which emphasizes the necessity of creating an established state where diverse cultural identities are accommodated, cultural differences are respected and tolerated, and the rights of excluded or marginalized cultural groups are recognized (also see [17]). The second approach, presented by Nick Stevenson, is from the perspective of cultural sociology, which shifts the focus of citizenship into common experiences, learning processes and discourses of empowerment (also see [29]). The most important dimension of the second approach concerns the cultural discourses in daily practices, 
whereby individuals conflate the personal and the political dimensions of citizenship and give rise to new demands for (cultural) rights in informal communicative situations and ordinary life experiences [6].

Cultural citizenship in the sense of cultural sociology, as I see it, offers a junction to bring Confucianism and citizenship together. The learning process, for example, is not only underlined by cultural citizenship where the cultural citizens embed the self into social relations and acquire knowledge about the self and the relationship of the self and others in daily practices $[6,29]$, but is also highlighted in Confucian thoughts where the self is an ethical one or whole, where 'particular kinds of obligations and entitlements by which we live varies largely according to the social roles that one plays' ([31], p.245). Moreover, cultural citizenship adopts a subjective perspective and focuses on the reflexivity and cognition of individual citizens; likewise, Confucianism attaches great importance to self-cultivating practices in order to make the superior man (junzi), who reflexively and autonomously achieves learning that is sound in theory and practice (neisheng waiwang). In addition, cultural citizenship stresses common experiences where individuals reach mutual understandings and learn to respect each other, which exactly resonates with Confucian key words such as compassion (ceyin), benevolence (ren) and forgiveness (shu). More importantly, although the term 'right' does not appear in Confucian texts, there are implicit elaborations with respect to 'right' or examples of citizenship right practices in Confucianism [15, 16, 28, 37].

In this chapter, I explore cultural citizenship for students who read Confucian classics in a classical school by examining the complexity and contestation of their cultural (moral) discourses. I understand 'citizenship', as Engin Isin ([12], p.371) claims, to be 'a dynamic ... institution of domination and empowerment that govern who citizens ... are and how these actors are to govern themselves and each other in a given body politic. Citizenship is not membership. It is a relation that governs the conduct of (subject) positions that constitute it' (italics in original). From the abovementioned perspective of cultural sociology, I regard cultural citizenship in this paper as a process of socio-symbolic practices to reflexively interpret one's social, cultural and political conditions by creating symbolic and social boundaries $[18]^{1}$ and constructively act to generate an identity or position and a reflexive understanding of it. More specifically, I will discuss Confucian cultural citizenship, a term that could be defined as a process to reflexively reconstruct one's conduct and ethical relations according to Confucian values in discursive and actual practices by drawing upon socio-symbolic boundaries. In this study, the exploration of cultural citizenship is accomplished by revealing the processes through which the classical school students are reflexively 'being made' and '(self) making' [23] (new) identities (positions), mainly through the symbolic and social space of classical education. In addition to the second part of methodology, the third section shows the individuality and ethicality in Confucian students' cultural discourses, and the fourth explores the practically discursive conflicts between individualism and authoritarianism, which are based on cultural hierarchy. In

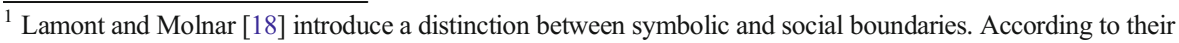
research, symbolic boundaries 'are tools by which individuals and groups struggle over and come to agree upon definitions of reality', while social boundaries 'are objectified forms of social differences manifested in unequal access to and unequal distribution of resources (material and nonmaterial) and social opportunities' ([18], p.168).
} 
the final remarks, I discuss the institutional predicament that Confucian students face on the basis of summarizing the conclusions derived from the previous parts.

\section{Research Methodology}

The resurgence of the Confucian classical school began in the mid-1990s in Mainland China, and has been growing rapidly in minjian (civil) society since the early 2000s. Among different types of classical education advocated by various individuals or cultural groups, the most popular and also the most influential is that of children reading classics (ertong dujing), primarily initiated by Dr. Wang Caigui, who has devoted his life to encouraging Chinese students, especially those under the age of 13 , to repeatedly read/memorize ancient Chinese classics. ${ }^{2}$ The core of the pedagogy proposed by Caigui is pure and massive (laoshi daliang) readings of classics, without having to understand the meanings of the classical texts. My fieldwork school faithfully follows Dr. Wang's educational philosophies and pedagogic practices. Different to most old-style small private schools (sishu) that have no official schooling credentials, my case school has a formal license issued by the local administration to offer primary and secondary education.

I carried out the first ethnographic fieldwork in the classical school in 2012, visiting again in 2013 and 2015. The two main methods of data collection are participant observation and informal interviews with students in the classroom or other places. As it was a boarding school where students were required to stay at school for entire weeks, I was allowed to live on campus and spend all day with students and teachers, thus I could conveniently participate in classroom interactions and daily practices and communicate with them in everyday situations. I interviewed 18 students in 2012 aged 12 to 22 , and had four group discussions in two classes made up of 31 students aged 14 to 18 in 2015 , both of which constitute the main data resources of this paper.

\section{Moral Boundaries, Individuality, and Ethicality: Moralizing the Self}

\section{Moral Boundaries}

When I asked students what changes the classical education (jingdian jiaoyu) has brought them, almost all of them responded by comparing their performances and experiences in the classical school with those in the state-maintained systematic schools (tizhi xuexiao). This is understandable, given that most students at the classical school once studied in the systematic schools and shared similar 'unhappy' experiences there. When they recalled the systematic schooling experience, they made use of moral discourses to draw symbolic boundaries by describing state-maintained education as

\footnotetext{
${ }^{2}$ According to Wang Caigui [35, 36], any education should primarily consider three principles: contents, methodology, and time. He claims that his theories of children reading classics best correspond to these three principles, that is to say, to teach students the best and highest wisdom in classics (contents) by repeatedly reading and memorizing (methodology) before the age of 13 years old, an age period when children are best at memorizing rather than comprehending (time). Based on this, he confidently asserts that classical education is consistent with the natural development of human nature.
} 
something immoral and explaining how they felt and why they dropped out. In an informal interview with students A and B, they criticized the current state-maintained educational system that goes against human nature and suppresses the development of students' moral conscience.

Student A: I think [systematic] education nowadays has been stifling children, making them dare not to tell the truth and blindly pursue their external performance, and finally, [systematic education] has become inhuman [educational institution].

Student B: [Systematic education] lets student learn how to deceive people. Saying that there is one question, if you do not know the answer, the teacher would beat you. And then the next time, when you encounter the same question, you still cannot deal with it, but when the teacher says whoever is able to solve it can raise their hands, you will raise your hand even if you do not know the answer.

\section{Student A: You're right.}

The 'immorality' of systematic education was asserted by almost all of my interviewees who had studied in the classical school for over 3 years. In their views, the 'immoral' systematic education encourages the 'mass production of "inferior products"', and therein 'products' refer to students, and 'inferiority' could be understood as 'immorality' or 'morally inferior'. Another issue of the 'immorality' of the bureaucratic educational system, as some of my interviewees claimed, was the inadequacy of independence and self-determination, especially for schools' principals and teachers. As one student told me, the 'moral weakness' of current systematic education is shown in the fact that teachers 'cannot make decisions by themselves', and consequently, even though 'they might realize education should not be [as it is nowadays], it has to be what it is now'. On the contrary, classical education was acclaimed as 'moral' by my interviewees, as a 14-year-old male student who began reading classics at six said:

Everyone has improved after reading classics, although in different aspects. Most are as such, but it does not exclude the few [who do not develop]. That the majority is moving in the right direction proves that, in the systematic schools, most people still stay at the starting line. I had a good friend who studied in the same class [in the systematic school]. When I returned [home] to visit him, [I saw] his hair covered one eye just in order to go with whatever was fashionable.

To most of my interviewees, the failure of systematic education to moralize citizens results from the examination-orientated (yingshi) approach that exerts high pressure by demanding students complete a large amount of homework on top of their arduous schoolwork. Almost all of my interviewees complained about the 'overload of homework' and 'endless examinations' that made them feel depressed, frustrated and finally weary of studying, which can also be regarded as a form of resistance to examinationorientated schooling. In addition, they objected to the pedagogic pattern by not doing homework, skipping classes, fighting with classmates, squabbling with teachers, or 
even stealing, according to my interviews. More importantly, examination-orientated education also created a school hierarchy based mainly on test scores or examination ranks, which not only puts students on different academic levels, but also morally hierarchizes their social network within the classroom. One of my interviewees, an 11year-old boy, shed tears when he told me about his previous experience in the systematic school, where students were divided into different hierarchies according to academic performances, and teachers treated 'good' students who achieved higher scores much better than 'bad' ones whose grades were lower. As he always ranked last in the whole class, he felt despised, neglected and was even cursed by teachers in the systematic school; moreover, he had no friends because no one would play with a 'bad' student. I was shocked when he said he would commit a crime or suicide if he had stayed there any longer. Additionally, my interviewees often labeled themselves as 'bad students' (huai xuesheng), not only according to their lower rank in academic performance but also in the light of 'bad' habits and manners in their eyes, such as going against the teachers, hanging out in the classroom, smoking, and fighting, which, as mentioned above, are also seen as resistance tactics by them.

On the other hand, they also began to reflect morally upon themselves to 'wipe out' the 'evil' practices, which empowered them with the courage to take action in order to break the link with systematic schooling. They attributed their 'moral degeneration', a phrase used by a student, to the 'immoral' configuration of the systematic school itself, whose practical aim was merely, according to my interviewees' viewpoints, to unify individual students into an easily regulated disciplinary pattern by establishing a rationally calculable and operable examination-score hierarchy. In other words, the moral suppression of the subjectivity from the examination-based hierarchy in the systematic schools ironically highlighted their individuality and generated a spirit of individual resistance, which encouraged the individuals to escape the burden of the dominating disciplinary model and turn to classical education for moral self-cultivation.

\section{Individuality}

Individuality, or the consciousness of one's own particularity, is a crucial characteristic embodied in my interviewees. Almost all of them expressed their aspiration to escape from the domination of systematic schooling when I asked about their initial motivation to read classics. They told me they enjoyed studying in the classical school firstly because the pressure of homework was completely released; they did not have to be censored or evaluated by the point-based hierarchy, as there were no examinations at all; and teachers and classmates treated them equally and considerately. In a word, to my interviewees, to read classics liberated their individuality from the domination of the state-maintained schooling system, and encouraged them to pay much attention on the cultivation of the self, as the following conversation between an interviewee (B) and me (A) shows.

\section{A: Do the teachers exert pressure on you to memorize [classics]?}

B: Of course not. As long as you do your best, any [performance] is appreciated, even if you fail to recite [the required contents]. To memorize only 100 characters is also considered an achievement. 
In reading a large number of classics, students, all of my interviewees included, were encouraged to be responsible, honest, moral and ethical. Another example is from a 9year-old girl who told me she felt at ease in memorizing classics because although she had just entered the classical school and had been there for only 2 months, the teacher did not push her to catch up with the whole class, rather she was allowed sufficient time to get used to the study methods, provided with a suitable study plan according to her own capabilities, encouraged to study by herself, and the teachers emphasized the importance of learning from the heart (yongxin xue).

Reading/memorizing classics was regarded as a process of moral transformation of the self to 'wipe out' the 'evil' habits, to eliminate 'uncivilized' behavior, and more importantly, to reconstruct a new and 'good' disposition. Central to the 'moral' merits was willpower (dingli), the key quality presumably to be cultivated in the classical education. One interviewee, when talking about what changes the memorization of classics brought about in him, said:

At the beginning, of course, it was boring. [You might ask yourself] why I have to read [classics] and what use it is. Very boring. Probably and gradually [you are] getting used to the boredom, [and it finally] turns out to become a matter of willpower, which increases your toughness in life. Now [I would] feel anxious if I did not read classics for a couple of days.

In the same vein, another interviewee told me that he even tore up the classical textbook when he started reading classics. As the classical pedagogy only requires students to spend the whole day memorizing Chinese and Western classics without any interpretations of the texts, most of my interviewees admitted that they felt uninterested in the classical mode of learning at the beginning. However, with the instruction of the teachers, they gradually learned to consider the boredom of memorization as a way of tempering their willpower, and a process of developing their capabilities in self-control and self-discipline. Hence, from their perspective, to persevere in memorizing an abundance of classics was a form of moral self-cultivation in order to overcome 'bad' qualities such as laziness, impatience, fickleness, lack of concentration and poor stamina.

Moral self-reflection also played an important role in transforming students into autonomous learners who were able to reflexively regulate study arrangements when they realized that it was for their own sake, instead of anything else, to abundantly memorize classics, as one interviewee told me:

I feel that [it is] not merely to memorize classical texts, but to transform a person as a whole. At the beginning, I didn't want to enter the classroom at all. One or two years later, little by little, [I've] got the desire to advance. [It's] not to do what other people want you to do, but to yourself aspire to make progress.

Self-motivation to learn is appreciated by Confucianism as a core attribute, hence the significant attention is paid to its cultivation in classical education, where students are deliberately shaped to become active learners whose inner dynamic results from a reflexive self-control of one's 'evil desires and sentimental impulses', as one student stated. To put it another way, by rationally increasing one's capabilities of self-control, 
self-discipline, self-management and self-supervision, one could exploit the inner motivation to learn. These self-governing qualities were overwhelmingly admired by the students, among whom one interviewee admitted feeling anxious and guilty if she could not finish her daily tasks of memorization. Indeed, she positioned her current self in opposition to her previous self in the systematic school, a person who 'was tired of study even if the academic performance was worse than others' and finally 'gave up on myself hopelessly'.

Along with the improvement of the moral self-governing self through abundantly memorizing classics, students gradually became aware of their life ambitions or career aspirations, clearly or vaguely, firmly or indecisively. For example, a 17-year-old girl told me she had 'set up a plan to engage in the cause of promoting classical education in the future'. By regarding reading classics in the classical school 'as a turning point where my life that had been going down was lifted up', she realized 'a sense of life direction'. Other interviewees disclosed their life dreams to become, for example, a Confucian philosopher, a physical scientist, or a businessman in the digital and technology sector. No matter how their life goals varied, all of my interviewees considered the memorization of classical texts as the foundation for achieving their goals. Another interviewee, who claimed that it was through reading classics that she slowly discovered her life's direction, quoted a sentence from the Confucian Analects, saying that "the Master said, "At 15 I set my heart upon learning.",3 As she stated, 'although I am later than Confucius, I've finally got one [life goal]. ... Consequently, I have no confusion [in my life].'

\section{Ethicality}

The moralization of students in the classical school not only generates the moral qualities of individuality, but also highlights the ethicality in my interviewees' moral discourses. Correspondingly, the self of a Confucian cultural citizen is one of individuality and ethicality, both of which are difficult to detach from one another because a moral/ethical self in Confucianism is reflexive and therefore able to reconstruct a rational relationship with itself as well as with others. An interviewee who had read classics in full-time education for 6 years when interviewed recounted his improved rationality in controlling his own emotions and learning how to conduct himself calmly:

Previously I was always disgruntled, and felt I could do anything [I wanted] as long as I was unhappy. But afterwards [I] felt that such behaviors were wrong, and would annoy others. [Since then] I have gradually changed myself. Being a man (zuoren) is to constantly struggle with one's self, not to fight with other people. Prior to reading classics I felt myself to be an angular stone, [but since I began reading classics, the edges and corners] have been grinded slowly.

The reflection upon one's self corresponds to the above-mentioned moralization whereby 'evil' habits can be removed and a 'good' disposition can be created, but here

\footnotetext{
${ }^{3}$ See Book II Wei Chang in Confucian Analects, translated by James Legge, Shanghai: Sanlian Bookstore, p.12.
} 
I highlight the ethical self, a concept of the self that is embedded in social relations. The moral enhancement of the self means one is able to rationally and reasonably deal with the ethical relations with his/her self by, as the interviewee disclosed, realizing that, for instance, his/her own conduct might cause trouble for other people. The moral feeling, specifically the sense of compassion, was the key point to associate one's self with others in social settings. According to Mencius, having sympathy for others is indicative of morality, ${ }^{4}$ which was also suggested by an interviewee who evaluated himself as a person who always took pity on people and believed that all humans were morally good inwards and were able to achieve moral enhancement.

Family ethics or the ethical reflection upon how to handle family relations was specifically stressed in students' discourses. One student informed me that the relationship with his parents was remarkably improved since he studied in the classical school, and he learned to talk with parents and think about problems from their point of view. He admitted that before reading classics, he 'seldom communicated with them at home,' at times having bitter quarrels. In his mind, it was reading classics that brought him ethical self-transformation. Another interviewee stressed the importance of filial piety (xiaoshun). By critically reflecting upon his previous disobedient behaviors, he realized he should patiently listen to their words, see things from their perspective, and help them with housework.

In the same vein, they also learned to be responsible to the family. For example, by applying the Confucian self-cultivating technique 'seeking the cause in oneself' ( $f a n$ qiu zhu ji), an interviewee recalled the experience after his parents divorced, and criticized himself for failing to actively and positively communicate with them but instead escaping by frequenting internet bars. Consciousness of responsibility was not confined to the family domain, but also extended to schooling. As a female interviewee told me, classics taught her how to get along well with classmates:

In the past, if someone hit me, I must hit back. [However,] now if someone beat me or someone else, I will ask him/her why do you hit people, and persuade him/ her [not to do it again]. ... When I see someone looking unhappy, I will help him/ her to find out the reason. I used to help people too, but not seriously. Now I genuinely dare to face [others], to work out [the problem]. I cannot only deal with my own [problems], but I also help others. When [you see] someone improve due to your help, you feel especially happy, happier than when you improve yourself!

At a more fundamental level, in moralizing the self through the memorization of classics, my interviewee reproduced two types of discourses: one is the individualistic, and the other is the ethical. The two do not oppose to each other, but go together to reconstruct new Confucian cultural citizens, who are not only able to independently regulate their own speech and behaviors and to autonomously stimulate themselves to study for the fulfillment of their life ambitions, but they also have the potential to creatively reshape the ethical relationship with their own 'selves' as well as with other people, whether at home or at school. This largely resonates with the term 'ethical self' portrayed by Nuyen ([22], p.132), which regards the Confucian self as 'not defined in

\footnotetext{
${ }^{4}$ See Book II Kung-sun Chau in The Works of Mencius, translated by James Legge, Shanghai: Sanlian Bookstore, pp.77-79.
} 
terms of the individual, but in terms of the relationship between the individual and his or her community.' Another echoed concept is 'moral individualism' coined by William Theodore De Bary ([5], pp.23-25), meaning that individuals achieve sustainable development of the self in ethical practices and moral interactions. As a result, my interviewees as whole achieved a new morally individual self-image, an independent, self-reliant, active, responsible, compassionate and benevolent self, which differed sharply from the repressed, hopeless, spiritless and passive self in the statemaintained systematic schools.

\section{Hierarchy, Authoritarianism, and Individualism: the Discursive Paradox}

The confusion that my interviewees encountered in learning classics by rote was how to deal with the contradiction between memorizing massive classics and incomprehension of them. In the struggle with it, they produced a type of hierarchical discourse by ascribing their difficulty in comprehending the classical connotations to their inferiority of cultural sophistication or low level of self-cultivation. Hence, in order to understand the principles of classical literature, in their views, they first needed to reach a cultural level as high as that of the authors. Memorizing a great number of classics was regarded as the foundation to increase one's cultural capability and moral hierarchy, as one interviewee stated,

First of all, as a person, if he wants to achieve something, he must jump out of himself to read the best books, the first-class books, to write first-class calligraphy, and to become the most superior person. [He] must stand on the highest point to look at problems down from the top.

The cultural discourses of hierarchy were also involved in creating students' notions of social interactions. By dividing people into different hierarchies according to their levels of wisdom, one interviewee held the opinion that one should 'listen to a person who has wisdom at a higher level', because she could 'obtain higher understanding of life so as to increase her own cultural level'. Furthermore, students also made use of hierarchical discourses to evaluate their teachers. For the most part, they admired the teachers at the classical school and considered them to be of profound insight or of 'high' wisdom. Consequently, they believed these teachers stood higher in the cultural/ moral/wisdom hierarchy, and as students, they should follow what teachers told them to do. This evokes the idea of authoritarianism, which played an important role in shaping students' mentality and ideology to become Confucian cultural citizens. The idea of a cultural/moral hierarchy functioned as the backbone of the notion of cultural $/$ moral authoritarianism, both of which were taken up by students for self-discipline. In other words, the basic reason why they thought it was 'right' to follow teachers' instructions and 'wrong' to contradict them was the culturally hierarchical conception that classified teachers to be of a higher grade and students of a lower grade. As one interviewee said,

I would like to say, [whether a teacher should be] democratic or authoritarian, it's up to what the students are. If for example all are little babies, they know nothing about democracy. ... I prefer an authoritarian teacher, because I myself know my 
knowledge is not profound enough yet, and the teacher knows more than me. Consequently, [whatever] the teacher says, my first feeling tells me she is right.

So I think an authoritarian teacher is important to me.

This view was shared by many other interviewees who perceived the obedience to the teacher as 'modesty', 'courtesy', 'having wisdom', and 'thoughtfulness', all of which were often cited during interviews by students who believed that as someone young whose life experience and wisdom were less than those of teachers, they were not 'qualified' to raise critical questions. The keyword 'qualification' here, according to my interviewees, referred either to one's capacity or eligibility to express different opinions from the classics or the teachers. In addition, teachers also used the word to produce culturally authoritarian and hierarchical discourses, which reversely created students' notion of obedience. One example was the head teacher of the classical school discouraged students from raising criticism against the tentative pedagogic reformation of reading English classics. As she said to the whole class formally and arbitrarily:

All students! Put down your stubbornness. Put down your prejudice. [Don't] consider yourself always right. Stop self-approbating. Put all your biases down. OK, let me say it again: just follow the new method. Insofar as the effects, you can discuss with me 3 months later, but do not argue with me now. Don't argue with me.

As a student told me, there was no discussion at all between students and teachers about the necessity of changing the methodology or how to employ the new learning approach. They were just required by the teacher to give up the previous type of study and turn to embrace the new one. Surprisingly, according to interviews with students, most of them neither felt anything 'incorrect' or 'morally bad' nor showed dissatisfaction or complaint about being deprived of the freedom to express their own individual opinions. Instead, they told me they agreed with what the head teacher said, that is, firstly to try the new method for 3 months, and then wait to see the effects. Not only did students not exhibit any argumentative attitudes, but also teachers faithfully complied with the new pedagogy that was originally raised by the principal, who was himself determined to promote the reform without negotiation with the other teachers. This case further showed the authoritarian governance structure of the classical school, in which the principal had the dominant power in school affairs while teachers and students lacked ways to express their different opinions in a public forum. To students, the authoritarian regime of the classical school conversely radicalized their notion of hierarchy and authoritarianism, which resulted in their 'silence' in school affairs and intensified their compliance with the teachers.

Authoritarianism, both in the cultural discourses and in the governing configuration, directly went against individualism, which trapped students in a morally contradictory situation. An interviewee who claimed to have grown up in an American-style democratic family where she was encouraged to do everything independently and equally negotiated any issues with her parents told me that she felt embarrassed and unhappy in her class because of the teacher's 
enforcement. By labeling herself as 'resistant', she recounted the experience of 'going against' the head teacher in the following conversation between her (B) and me (A).

A: Does the unhappiness come from the teacher?

B: Yes. I think the teacher also has ... Between the head teacher and me there is ... Anyway I think I have ... I have a kind of resistance. I am a resistant.

A: Do you go against the head teacher?

B: Not that kind of resistance. What I mean is, if someone has a different opinion from mine, I will put forward my own views, regardless of her being happy or unhappy.

A: What opinions of the head teacher did you argue against?

B: [When] she raised a point of view, no one would dare to contradict, but I would say [something different] secretly in my heart.

A: Did you want to argue?

B: Yes I did.

A: Did you once argue?

B: Yes I did.

A: And as a result ...

B: [I was] educated by criticism. I think she was much better [than other teachers], just to educate me in private.

A: Well, not in the class?

B: No. But there was still pressure.

However, more of my interviewees disagreed with opposing teachers and criticized 'going against' their authority as 'a bad habit' or the display of the 'immoral disposition'. As a student argued, 'the teacher is teacher and the student is student in Chinese educational background, and it must have been the same since ancient times.' They defended the authority of teachers, and even asserted that an authoritarian teacher was someone who truly took responsibility to propagate the wisdom of the classics to assure students' 'correct' way of life in the future. They claimed that it did not accord with the custom (he guiju) to offend the teacher in public even if the teacher indeed made a mistake. According to one interviewee, 
In my opinion, if a student, in front of everybody, purposely makes difficulties for the teacher or deliberately contradicts the teacher, it shows he does not understand the Dao. Usually we say 'I don't know' (wo bu zhi dao). In fact what he does not know is the Dao, which is the 'truth' (daoli). Going against the teacher in public is not in line with the truth in any case.

The well-disciplined manners of obeying the authority of the teacher were disclosed to be the core of the 'truth' in students' eyes. It is noteworthy that students embraced the value of compliance with teachers not blindly but reflexively, on the basis of reflecting upon the suitability of their conduct in terms of the Dao (the Way) in social interactions. The 'truth' or the Dao referred to here, according to my interviewees, is linked to the doctrine of the mean (zhongyong), whose intention was neither to make the teachers embarrassed in front of other people nor to keep silent if the teacher did make mistakes. Instead, as several of my interviewees stated, the appropriate situation was in private where students could express different opinions to teachers.

\section{Concluding Remarks: the Institutional Dilemma}

In cultivating students into a new version of Confucian cultural citizens, the discourses of individuality have contributed on the one side to these students disentangling their relationship with the 'immoral' state-maintained systematic schools and on the other side to their consciousness of their cultural right to choose the 'morally good' classical education. In the meantime, the dynamic of being an independent and autonomous self was not aimed at cutting off their social relations with others, but directed their efforts towards a moral self-transformation by embedding the value of individuality into an ethical relationship, which was a process through which they became moral individuals who not only had the qualities of self-regulation, self-management, self-supervision and self-development, but were also able to reflexively show compassion and responsibility for others.

However, there existed a problematic tendency to inhibit the moral self-governing individuality by the authoritarian discourses and practices, which were based on the notion of a cultural/moral hierarchy, making students regard teachers as superior to themselves in both cultural capabilities and moral cultivation, and consequently legitimizing their obedience to teachers. While almost all of my interviewees described their teachers in similar language to their own parents and felt like they were at home when studied in the classical school, they not only took it for granted if the teachers, for example, punished them by hitting their hands, but also appreciated teachers for taking responsibility for their personal development and moral improvement. In brief, the practical and discursive paradoxes, at their core being individualism versus authoritarianism that is based on cultural hierarchy, reveal the complexity and intricacy of creating Confucian cultural citizens in contemporary China.

If one puts the paradox of forging Confucian cultural citizenship in the context of a wider social perspective, we may find it is actually part of the moral contradictoriness of the Chinese path to individualization, where the entanglement of old and new ethics, of collective and individualistic values, and of responsibility-centered and rightscentered moral practices, has constituted a challenge to contemporary China's moral 
landscape ([40], p.72). As Yan [39, 40] convincingly argued, the most fundamental change in post-Mao Chinese society has been the rise of the individual, and the individual has for the first time become an independent unit in Chinese public discourses. Although Yan partially presupposes that Confucian ethics emphasize the absolute primacy and supremacy of the collective over the individual ([40], p.43), my research reveals a different social fact that Confucian education not only philosophically pays attention to cultivating the individualistic spirit but also actually 'awakens' students to become a moral and self-governing individual. More importantly, critical reflection upon the 'immorality' of the state-maintained systematic schools, as mentioned earlier, together with the enhancement of moral individualism in reading classical literature, further transformed the 'self' consciousness of students into an awareness of cultural citizenship rights, especially when they gradually acquired the qualities and abilities of self-choice and self-determination.

This shows that moral reflexivity or ethical reflection serves as a dynamic for individuals to dis-embed from an old social category (i.e. the state-sponsored educational regime) and to re-embed in a new type (i.e. the private classical school). The dimensions of dis-embedding and re-embedding are two fundamental aspects in the individualization theory ([1], p.128). Although the individualization theory also indicates a third dimension, namely the loss of traditional security [1], the case of classical students in my research exhibits an opposite story that the reconstructed 'traditional' security in the old-style Confucian private school was exactly what individuals pursued, whereas the 'modern' security in the systematic schools was what they aimed to reject. There was a reversal in the cultural discourses reproduced by students in the classical school, indicating that the 'modern' (specifically, systematic education) was expressed as the 'backward' method of education while the 'ancient' (classical education) was seen as the more 'advanced'. In terms of Beck's compressed modernity [3, 39, 40], 'pre-modern' Confucian education was strategically transformed into a 'modern' ('advanced') concept, while 'modern' state-maintained education was tactically labeled as a 'premodern' ('backward') idea. There is indeed a symbolic 'compressed modernity' ('pre-modern' and 'modern') coexisting in students' discursive repertoires, but it also shows the reverse strategic manipulation of the discursive boundaries.

More importantly, from a wider societal perspective, the resurgence of Confucian individualism in particular and the revival of cultural conservatism in general are occurring in the context of reflexive modernization, a type of modernity that confronts or even deconstructs itself unconsciously in an institutional way ([2], pp.175-77; [9], pp.36-40). Specific to this case, Confucian thoughts are being employed by the individualized students as a potential negating power against the modern systematic school itself, at least in the subjective domain. Admittedly, it is too rash to conclude that the revival of classical cultural values has constituted the deconstruction of the overall modern values established by the socialist party-state. As a matter of fact, as I will discuss later, it is more productive to see it the other way around. Nonetheless, at the very least, the reappearance of Confucian ethics indeed promotes the development of moral individualism that may be considered as part of the Chinese individualization process, which directly challenges the legitimacy of state-sponsored systematic education, a 'modern' educational configuration established for the pursuit of modernity since the early twentieth century. 
However, students' moral individualization is also influenced, directly or indirectly, by the state and society. As Yan ([39], p.509) comprehensively demonstrates, Chinese individualization is a party-state managed pattern, whereby the state plays a key role in directing the flow of individualization. Nevertheless, Yan underestimates the role of society. In my research, both the state and society (specifically, the job market) contribute to the development of Confucian cultural citizenship, and result in an institutional quandary for students in the classical school. Specifically, in claiming their cultural right to choose the 'morally good' education they prefer, students were trapped into a social dilemma about their citizenship status, where on the one hand they asserted the cultural legitimacy of reading classics in order to become genuine Chinese citizens and on the other hand they were anxious about their education experience being recognized and denounced either by the state or by the market. Specific to my case study classical school, even though it was officially awarded with a legal license by the local government to run a school for young people's compulsory education, it had not systematically set up state-stipulated compulsory courses, such as Chinese language, mathematics, English language, and science. As a result, students worried about failing to 'connect the dots' (jiegui) with the education in the systematic schools. Indeed, almost all of my interviewees expressed their thoughts of 'returning to the systematic schools' (huigui tizhi), as they perceived it to be an institutional guarantee to secure an academic certificate officially acknowledged by the state and the job market. The anxiety worsened among the older students, who faced the crossroads of either entering a higher school or going to university, as a 17-year-old male interviewee told me:

This question [going to university] must be considered! This is my feeling. I have to think about it as well as other things in the future. A person cannot be too idealistic. He must have an ideal, but he cannot be too idealistic. Otherwise he would be lost, just thinking, thinking, and thinking, [but the mind is] empty.

The most fundamental factor provoking their anxiety was the achievement of a recognized diploma from a university or college, which in my opinion can be seen as an embodiment of institutionalized security that might to a certain extent assure students' social status. Another example that is indicative of the anxiety about social status was the story of 'an excellent representative student (A) in the circle of classical education' as an interviewee (B) told me. Student A had insisted on reading classics for nearly a decade up to 2012, the longest period of time for a student I had ever heard, but gave it up and left the school, and was engaged in an insignificant job. In the view of interviewee B, the story of student A exacerbated student B's anxiety about the social status of students who read classics for many years:

He is such a top student, no matter in the systematic school or in the classical school, so smart and able to learn everything extraordinarily fast. But such an outstanding student is now at such a low status. So his story has caused some [negative] influence on both students and parents [in the classical school].

As a result, many of my interviewees began to feel suspicious of the 'usefulness' of reading classics. In ancient China, the direct purpose of reading classics was for the imperial examination $(k e j u)$, through which one could acquire certain social status if he 
succeeded. However, since the system was institutionally abolished in the early twentieth century, the purpose of reading classics has become a problem. To revive Confucianism requires re-legitimizing the values, significance or 'usefulness' of reading classics. Although my interviewees said they clearly knew and faithfully believed the morally beneficial effects of the wisdom in classical texts, they still could not persuade themselves to undertake the huge uncertainties and enormous risks inherent in classical education, unrecognized by the state and society alike. Therefore, a substantial number of my interviewees admitted that they had no plan to keep on reading classics 'forever', but instead aspired to go to university. They held the view that studying in the university not only endowed them with a diploma but also enhanced their all-round competency for future employment. In their view, a university diploma was an indispensable prior condition for securing a job, as one student said:

Many high-level companies require an advanced degree. They do not at first see how good your knowledge is, but set the threshold of the degree. Anyone who wants to work for these companies must meet their standard, or else you have no opportunity at all to cross the threshold of the initial interview, even if you have great learning.

However, while facing such institutional uncertainties, some of my interviewees drew moral boundaries by denigrating Chinese universities. In their eyes, Chinese universities were a place where, as several interviewees described, students 'degenerated' and 'became irresponsible', disliked learning, skipped classes, and spent all day playing games and hanging out with their partners. Thus it seemed worthless to 'waste 4 years merely for a diploma', as one student told me. Indeed, many of my interviewees believed that moral cultivation (at which their classical education was especially aimed) should be of more importance than an academic certificate, and therefore their cultural right of reading classics in a private classical school should be recognized socially, culturally and politically. Nonetheless, they were still caught in a socio-discursive dilemma that on the one hand, they claimed for the moral legitimacy of their cultural rights in terms of discursive resources, but on the other hand, they had to anchor their hopes in obtaining a university diploma so as to relieve the anxiety of not being recognized by the state and society in a professional setting.

All in all, classical school students have to contend with practically discursive paradoxes within Confucian education to reform the self to become Confucian cultural citizens, being individualistic, self-disciplined, self-reliant and selfgoverning, as well as obedient, filial, benevolent and responsible. Yet they also face an institutional predicament in their efforts to strive for recognition of their cultural citizenship from the state and society alike. Therefore, as morally reflexive and ethically individualistic citizens, they have to establish a better position in order to cultivate a more consistent and compatible package of Confucian cultural citizenship. Institutional reform in the educational system is fundamental in order to create a more tolerant cultural-political environment and provide support to the private classical school, and finally to establish a systematic bridge to connect classical education with the next stage of advanced studies either in classical educational institutions or in state-maintained schools. 
Open Access This article is distributed under the terms of the Creative Commons Attribution 4.0 International License (http://creativecommons.org/licenses/by/4.0/), which permits unrestricted use, distribution, and reproduction in any medium, provided you give appropriate credit to the original author(s) and the source, provide a link to the Creative Commons license, and indicate if changes were made.

\section{References}

1. Beck, Ulrich. 1992. In Risk society: Towards a new modernity, ed. Ritter Mark. London: Sage Publications.

2. Beck, Ulrich, Anthony Giddens, and Scott Lash. 1997. Reflexive modernization: Politics, tradition and aesthetics in the modern social order. Cambridge: Polity Press.

3. Beck, Ulrich, and Edgar Grande. 2010. Varieties of second modernity: The cosmopolitan turn in social and political theory and research. British Journal of Sociology 61(3): 409-443.

4. Chan, Joseph. 2004. Exploring the nonfamilial in confucian political philosophy. In The politics of affective relations: East Asia and beyond, ed. Chaihar Hahm and Daniel A. Bell. Lanham: Lexington Books.

5. De Bary, William Theodore. 1983. Zhongguo de Ziyou Chuantong (The liberal tradition in China). Trans. Hongqi Li. Hong Kong: The Chinese University Press (In Chinese).

6. Delanty, Gerard. 2002. Two conceptions of cultural citizenship: A review of recent literature on culture and citizenship. The Global Review of Ethnopolitics 1(3): 60-66.

7. Engin F., Isin. 2002. Citizenship after orientalism. In Handbook of citizenship studies, ed. Engin F. Isin and Bryan S. Turner, 117-128. London: Sage Publications.

8. Fukuyama, Francis. 1995. Confucianism and democracy. Journal of Democracy 6(2): 20-33.

9. Giddens, Anthony. 1990. The consequences of modernity. Cambridge: Polity Press.

10. Huntington, Samuel P. 1991. Democracy's third wave. Journal of Democracy (2).

11. Isin, Engin F. 2008. Theorizing acts of citizenship. In Acts of citizenship, ed. Engin F. Isin and Greg M. Nielsen, 15-43. London: Zed Books Ltd.

12. Isin, Engin F. 2009. Citizenship in flux: The figure of the activist citizen. Subjectivity 29: 367-388.

13. Isin, Engin F. 2012. Citizenship after orientalism : An unfinished project. Citizenship Studies 16(5-6): 563-572.

14. Janoski, Thomas. 2015. Citizenship in China: A comparison of rights with the east and west. In Theorizing Chinese citizenship, ed. Zhonghua Guo and Sujian Guo, 23-47. Lanham: Lexington Books.

15. Kim, Sungmoon. 2008. The orgin of political liberty in Confucianism: A nietzschean interpretation. History of Political Thought XXIX(3): 393-415.

16. Kim, Sungmoon. 2015. Confucianism, moral equality, and human rights: A Mencian perspective. American Journal of Economics and Sociology 74(1): 149-185.

17. Kymlicka, Will, and Wayne Norman. 2000. Citizenship in diverse societies. Oxford: Oxford University Press.

18. Lamont, Michèle, and Virág Molnár. 2002. The study of boundaries in the social sciences. Annual Review of Sociology 28(1): 167-195.

19. Liu, Qingping. 2004. Rujia Lunli Yu Shehui Gongde: Lun Rujia Lunli de Shendu Beilun (Confucian ethics and public virtues: On the paradox of Confucian ethics). Zhexue yanjiu (Philosophical Researches) 1: 37-41 (In Chinese).

20. Liu, Qingping. 2007. Confucian ethics and social morality: The deep paradox of Confucian ethics. Contemporary Chinese Thought 39(1): 15-24.

21. Marshall, T.H. 1992. Citizenship and social class. In Citizenship and social class, ed. T.H. Marshall and Tom Bottomore, 1-51. London: Pluto Press.

22. Nuyen, A.T. 2002. Confucianism and the idea of citizenship. Asian Philosophy: An International Journal of the Philosophical Traditions of the East 12(2): 127-139.

23. Ong, Aihwa, Virginia R. Dominguez, and Jonathan Friedman, et al. 1996. Cultural citizenship as subjectmaking: Immigrants negotiate racial and cultural boundaries in the United States. Current Anthropology 37(5): 737-762.

24. Park, Chong-Min, and Doh Chull Shin. 2006. Do Asian values deter popular support for democracy in South Korea? Asian Survey 46(3): 341-361.

25. Rosaldo, Renato. 1994. Cultural citizenship and educational democracy. Cultural Anthropology 9(3): 402-411.

26. Rosaldo, Renato. 1994. Cultural citizenship in San Jose, California. Polar 17(2): 57-64. 
27. Rosaldo, Renato. 2003. Introduction: The borders of belonging. In Cultural citizenship in Island Southeast Asia: Nation and belonging in the Hinterlands, ed. Rosaldo Renato, 1-15. Berkeley: University of California Press.

28. Sim, May. 2013. Confucian values and human rights. The Review of Metaphysics 67(1): 3-27.

29. Stevenson, Nick. 2001. Culture and citizenship: An introduction. In Culture and citizenship, ed. Nick Stevenson, 1-14. London: Sage Publications.

30. Stevenson, Nick. 2003. Cultural citizenship: Cosmopolitan questions. London: McGraw-Hill Companies.

31. Tiwald, Justin. 2012. Confucianism and human rights. In Handbook of human rights, ed. Cushman Thomas, 244-254. New York: Routledge.

32. Turner, Bryan S. 1993. Preface. In Citizenship and social theory, ed. Bryan S. Turner, vii-xii. London: Sage Publications.

33. Turner, Bryan S. 1994. Postmodern culture/modern citizens. In The condition of citizenship, ed. Bart van Steenbergen, 153-168. London: Sage Publications.

34. Turner, Bryan S. 2001. Outline of a general theory of cultural citizenship. In Culture and citizenship, ed. Nick Stevenson, 162-190. London: Sage Publications.

35. Wang, Caigui. 2009. Jiaoyu de Zhihuixue (Wisdoms of education). Nanjing: Nanjing University Press (In Chinese).

36. Wang, Caigui. 2014. Dujing Ershi Nian (Two decades of reading classics education). Beijing: Zhonghua Book Company (In Chinese).

37. Wang, Canglong. 2015. Confucianism and citizenship: A review of opposing conceptualizations. In Theorizing Chinese citizenship, ed. Zhonghua Guo and Sujian Guo, 49-81. New York: Lexington Books.

38. Weber, Max. 1981. In General economic history, ed. F.H. Knight. London: Transaction Publishers.

39. Yan, Yunxiang. 2010. The Chinese path to individualization. British Journal of Sociology 61(3): 489-512.

40. Yan, Yunxiang. 2011. Chapter one: The changing moral landscape. In Deep China: The moral life of the person, ed. Arthur Kleinman, Yunxiang Yan, and Jing Jun, et al., 36-77. Berkeley: University of California Press.

41. Yi, Lin. 2015. Modernity, mobility, and dilemma: The making of Tibetan cultural citizenship through an English training program. In Theorizing Chinese citizenship, ed. Zhonghua Guo and Sujian Guo, 209-29. Lanham: Lexington Books.

Canglong Wang is a $\mathrm{PhD}$ candidate of sociology at the University of Edinburgh, UK. His work has focused on exploring the cultural, social and political dynamics in the making of Confucian citizens, both empirically and theoretically. He is the author of Confucianism and Citizenship: A Review of Opposing Conceptualizations, published in the book Theorizing Chinese Citizenship (Lanham: Lexington Books, 2015), and some publications that appeared in different Chinese core journals. 